\title{
KAJIAN DAYA TERIMA MINUMAN REMPAH DENGAN PENAMBAHAN LADA HITAM
}

\section{Hanifa Tyas Nabilah, Ismi Hanik Wulandari, Khumaidi, dan Esteria Priyanti*}

Akademi Kesejahteraan Sosial Ibu Kartini

Jl. Sultan Agung No.77, Gajahmungkur, Kec. Gajahmungkur

Kota Semarang, Jawa Tengah 50232

*esterpriyanti@gmail.com

\begin{abstract}
Abstrak
Penambahan lada hitam pada minuman rempah dapat memberikan nilai tambah pada minuman tersebut. Konsumsi minuman rempah dapat membantu menjaga daya tahan tubuh. Tujuan penelitian ini yaitu menentukan daya terima konsumen terhadap minuman rempah dengan penambahan lada hitam. Bahan yang digunakan yaitu jahe, kunyit, serai, lada hitam, air dan gula merah. Tahapan penelitian terdiri dari 3 tahap. Tahap pertama meliputi persiapan bahan dan alat serta formulasi minuman rempah. Tahap kedua yaitu proses pembuatan 2 jenis formula yaitu minuman rempah tanpa penambahan lada hitam dan dengan penambahan lada hitam. Tahap ketiga yaitu uji hedonik melibatkan 35 panelis tidak terlatih. Data yang diperoleh dari hasil uji hedonik dianalisis secara deskriptif menggunakan Microsoft Excel 2019. Untuk menentukan perbedaan daya terima terhadap rasa, warna dan aroma menggunakan uji Mann Whitney U Test pada software SPSS 25.0 for MacOS. Hasil penelitian menunjukkan bahwa rerata daya terima panelis terhadap rasa dan aroma berbeda secara signifikan $(\mathrm{p}<0,05)$, sedangkan terhadap warna tidak berbeda secara signifikan ( $>0,05)$. Hal ini menunjukkan terdapat pengaruh yang signifikan dari penambahan lada hitam terhadap rasa dan aroma pada minuman rempah, tetapi tidak pada warna. Dapat disimpulkan bahwa penambahan lada hitam pada pembuatan minuman rempah dapat menjadi inovasi baru untuk produk minuman rempah.
\end{abstract}

Kata Kunci : Minuman Rempah, Lada Hitam, Uji Hedonik, Daya Terima

Submit: 5 Maret $2021 *$ Revisi: 18 Maret $2021 *$ Accepted: 28 Maret 2021 * Publish: 10 Mei 2021 


\section{PENDAHULUAN}

Tubuh manusia memiliki sistem kekebalan tubuh untuk mencegah tubuh terserang penyakit. Sistem kekebalan tubuh atau yang sering disebut dengan sistem imun merupakan sekelompok sel yang bekerja sama melawan berbagai hal yang berbahaya bagi tubuh (Antari, 2017). Untuk itu sangat penting untuk menjaga sistem kekebalan tubuh. Konsumsi minuman rempah merupakan salah satu alternatif yang secara ilmiah terbukti baik langsung atau tidak langsung dapat membantu meningkatkan daya tahan tubuh. World Health Organization (WHO) menyatakan sekitar $80 \%$ penduduk dunia menggunakan pengobatan tradisional yang berasal dari tumbuhan (Ningsih, 2016).

Obat herbal disebut juga obat tradisional, merupakan obat yang terbuat dari ekstrak tumbuhan tanpa menggunakan campuran bahan kimia. Bahan utama obat herbal terbuat dari bahan alami seperti buah, batang, akar, daun, dan bagian tumbuhan lainnya yang disebut rempah-rempah. Obat herbal sering digunakan untuk mengobati atau menjaga kesehatan bagi tubuh sebagai pengganti obat kimia. Selain itu, kandungannya jarang memiliki efek samping dan khasiatnya yang ampuh (Mulyani et al., 2017). Nama lain obat herbal yaitu jamu atau minuman rempah. Dari banyaknya jenis tanaman yang masuk ke dalam kategori rempah, jenis yang paling popular dijadikan sebagai jamu atau minuman rempah antara lain serai, jahe dan kunyit.

Jahe (Zingiber officinale), Kunyit (Curcuma longa L) dan Sereh (Cymbopogon nardus L) dikenal oleh masyarakat Indonesia sebagai bumbu olahan pangan maupun untuk bahan baku pembuatan minuman rempah. Jahe memiliki sifat antivirus yang mampu menangkal Human Respiratory Syncytial Virus (HRSV) atau virus dalam sel sel saluran pernafasan manusia. Jahe segar dapat menghambat pembentukan plak pada saluran pernafasan yang disebabkan oleh HRSV sebanyak 12,9\% (Afifah, 2020). Kunyit mengandung kurkumin yang merupakan pigmen penghasil warna kuning. Uji coba in vitro yang telah dilakukan terhadap khasiat kurkumin. Kurkumin memiliki sifat sebagai sebagai antikanker, antioksidan, antiartitik, antiamiloid, antiischemic dan antiinflamantori (Hakim, 2015). Serai mempunyai banyak manfaat bagi kesehatan tubuh manusia karena mengandung minyak esensial, bahan aktif, mineral, vitamin dan antioksidan penting bagi tubuh. Minyak esensial yang dimiliki oleh serai meliputi myrcene, citronellol, methyl heptenone, dipentene, geraniol, limonene, geranyl acetate dan nerol. Minyak esensial tersebut berperan penting dalam mengatasi iritasi serta memiliki sifat sebagai insektisida, antifungi dan antiseptik.

Telah banyak penelitian yang mengembangkan produk minuman dengan menggunakan bahan dasar jahe, kunyit atau serai. Penelitian dari Rizal Yulianto \& Dewanti Widyaningsih (2013) menghasilkan produk minuman herbal dengan menggunakan bahan dasar cincau hitam, jahe dan kayu manis. Penelitian lain dari Nutrisia et al. (2018) menemukan formula wedang secang sebagai minuman kemasan rendah kalori yang menggunakan bahan kayu secang, jahe, cengkeh, serai, kayu manis, kapulaga, pala, mesoyi, kedawung, klabet, lada dan daun stevia. Penelitian dari A'yunin et al. (2019) telah menguji aktivitas antioksidan pada minuman jamu kunyit asam dengan penambahan jeruk nipis dan sirih. Hasil penelitian 
tersebut menunjukkan bahwa aktivitas antioksidan tertinggi pada minuman jamu kunyit asam dengan penambahan sirih. Adapun penelitian oleh Novitasari (2020) menghasilkan inovasi minuman herbal kemasan botolan menggunakan serbuk biji buah pokat dengan varian rasa dari teh celup.

Masih sedikit penelitian yang melakukan modifikasi resep minuman rempah dengan menggunakan bahan dasar jahe, kunyit, serai dengan menambahkan lada hitam. Lada hitam (Piper nigrum) mengandung piperin yang berfungsi sebagai antioksidan, antivirus dan antihipertensi. Piperin merupakan komponen utama alkaloid yang terkandung di dalam lada hitam. Lada hitam sering dimanfaatkan sebagai obati diare, anti inflamasi, dan perut mulas (Sunaryo, 2015). Penambahan lada hitam pada minuman rempah dapat memberikan nilai tambah pada minuman tersebut.

Berdasarkan latar belakang tersebut, peneliti melakukan pengembangan produk minuman rempah dengan penambahan lada hitam. Minuman rempah yang dikembangkan yaitu minuman rempah berbahan dasar jahe, kunyit, serai dengan penambahan lada hitam yang siap minum. Tujuan penelitian ini yaitu mengetahui daya terima konsumen terhadap minuman rempah dengan penambahan lada hitam.

\section{METODOLOGI PENELITIAN}

\section{Bahan dan Alat}

Bahan yang digunakan pada penelitian ini meliputi jahe, kunyit, serai, lada hitam, air dan gula merah. Peralatan yang digunakan meliputi kompor, timbangan digital, gelas ukur, cutting board, pisau, kom adonan, panci, ladle dan saringan.

\section{Waktu dan Lokasi Penelitian}

Eksperimen pembuatan minuman rempah dengan penambahan lada hitam dilaksanakan pada bulan November 2020 sampai dengan Januari 2021. Lokasi penelitian di Laboratorium Utama Program Studi Seni Kuliner Akademi Kesejahteraan Sosial Ibu Kartini Semarang. Pelaksanaan uji hedonik dilakukan di Pesantren Daarun Najaah, Jalan Stasiun, Kelurahan Jerakah, Kecamatan Tugu, Kota Semarang.

\section{Tahapan Penelitian}

Penelitian ini terdiri dari 3 tahap. Tahap pertama meliputi persiapaan bahan dan peralatan, serta penentuan formulasi minuman rempah. Tahap kedua yaitu eskperimen pembuatan minuman rempah. Tahap ketiga yaitu uji hedonik.

Formula dan proses pembuatan dimodifikasi dari resep Akbar (2020). Proporsi bahan pada pembuatan minuman rempah dapat dilihat pada Tabel 1. Produk minuman rempah tanpa penambahan lada hitam disebut sebagai F1 (Formula 1) dan produk dengan penambahan lada hitam disebut sebagai F2 (Formula 2). Proses pembuatan sampel minuman rempah dapat dilihat pada Gambar 1.

Tabel 1. Formula Minuman Rempah

\begin{tabular}{|l|c|c|}
\hline \multicolumn{1}{|c|}{ Nama Bahan } & F1 & F2 \\
\hline Jahe gajah (g) & 50 & 50 \\
Kunyit (g) & 50 & 50 \\
Serai (g) & 50 & 50 \\
Gula merah (g) & 150 & 150 \\
Air (L) & 2 & 2 \\
Lada hitam (g) & - & 8 \\
\hline
\end{tabular}

Uji hedonik digunakan untuk menentukan daya terima terhadap rasa, warna dan aroma produk tersebut. Uji 
hedonik melibatkan 35 panelis tidak terlatih. Panelis menerima sebanyak 2 (dua) sampel minuman rempah untuk dinilai, terdiri dari sampel minuman rempah tanpa penambahan lada hitam dan sampel minuman rempah dengan penambahan lada hitam. Panelis mengisi kuesioner yang menggunakan skala hedonik dengan kriteria sangat suka, suka, cukup suka, tidak suka, dan sangat tidak suka. Kriteria tersebut diberi skor 5 untuk sangat suka, skor 4 untuk suka, skor 3 untuk cukup suka, skor 2 untuk tidak suka, dan skor 1 untuk sangat tidak suka.

\section{Analisis Data}

Data yang diperoleh dari hasil uji hedonik dianalisis secara deskriptif menggunakan Microsoft Excel 2019. Untuk mengetahui perbedaan daya terima terhadap rasa, warna dan aroma dari kedua produk menggunakan uji Mann Whitney U Test pada software SPSS 25.0 for MacOS.

\section{HASIL DAN PEMBAHASAN}

\section{Rasa}

Nilai rerata daya terima panelis terhadap rasa minuman rempah dapat dilihat pada Gambar 2.

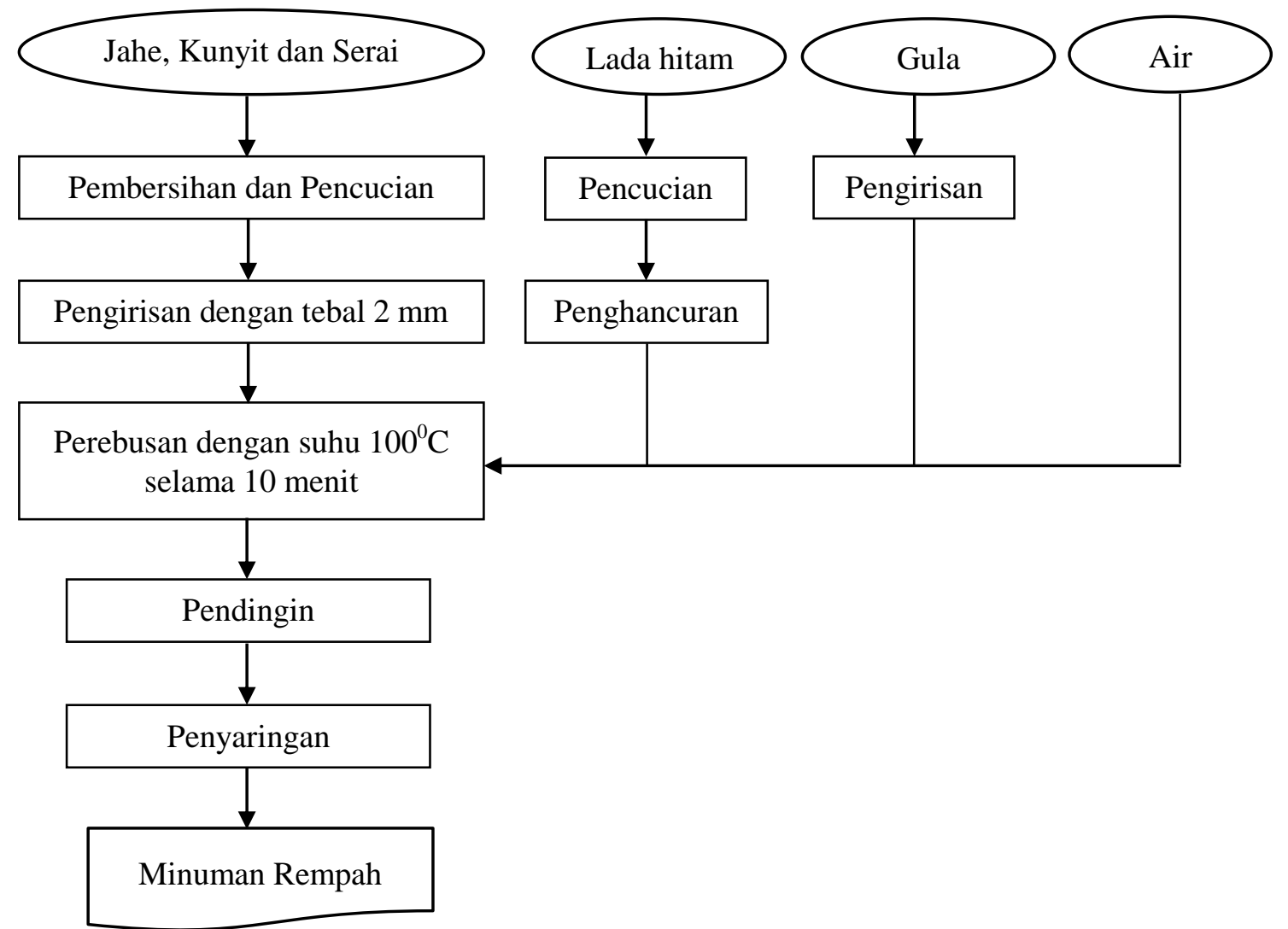

Gambar 1. Diagram Alir Proses Pembuatan Sampel Minuman Rempah dengan Penambahan Lada Hitam 


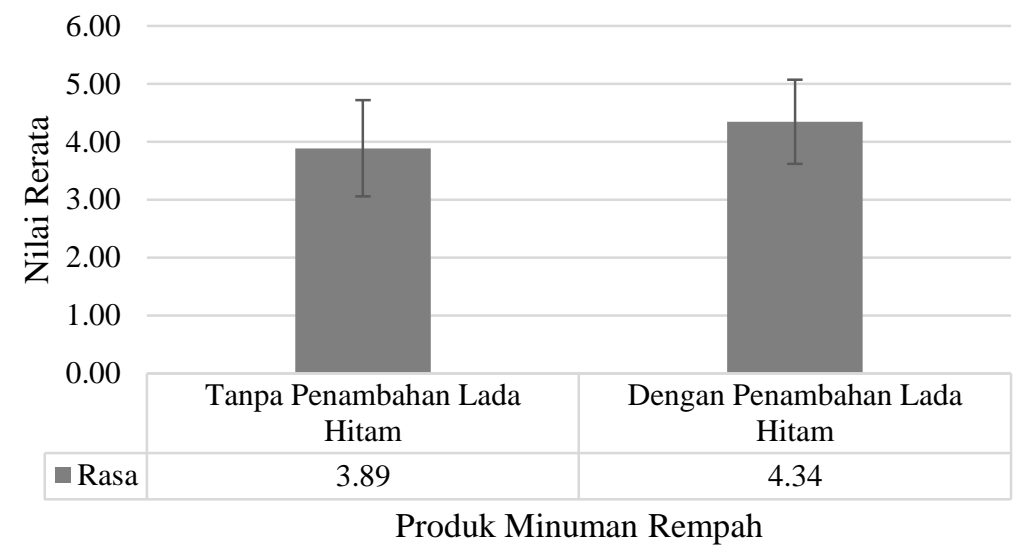

Gambar 2. Nilai Rerata Daya Terima Panelis terhadap Rasa Minuman Rempah dengan Penambahan Lada Hitam

Berdasarkan Gambar 2, diketahui nilai rerata daya terima tertinggi terhadap rasa yaitu pada minuman rempah dengan penambahan lada hitam. Nilai rerata yang dihasilkan sebesar $4,34 \pm 0,73$ dalam rentang penilaian sangat suka.

Berdasarkan uji Mann Whitney $U$ Test, diperoleh nilai Asymp sig 0,020 $(\mathrm{p}<0,05)$. Dapat disimpulkan ada perbedaan daya terima terhadap rasa antara kedua produk minuman rempah. Karena ada perbedaan yang signifikan maka dapat dikatakan bahwa ada pengaruh penggunaan lada hitam terhadap rasa minuman rempah.

Secara umum, penambahan lada hitam pada produk minuman membantu untuk menguatkan rasa jahe, kunyit dan serai, sehingga menghasilkan kombinasi rasa pedas dan manis yang pas. Kombinasi rasa yang pas menunjukkan proses ekstraksi pada saat perebusan berlangsung dengan baik. Kondisi tersebut dapat dipengaruhi oleh adanya proses penghancuran lada hitam dan pengirisan jahe, kunyit serta serai sebelum direbus. Proses tersebut dapat membantu menghasilkan rasa yang optimal saat perebusan (Dyah et al., 2015). Selain itu, rasa pedas dan panas dari produk minuman rempah dipengaruhi oleh penambahan lada hitam. Lada hitam mengandung piperin dan chavicine yang merupakan isomer basa piperin. Chavicine memiliki sifat yang mirip dengan capsaicin yaitu senyawa yang terdapat pada cabai merah yang menimbulkan rasa pedas dan panas (Pratama, 2017).

\section{Warna}

Nilai rerata daya terima konsumen terhadap warna minuman rempah dengan penambahan lada hitam dapat dilihat pada Gambar 3. 


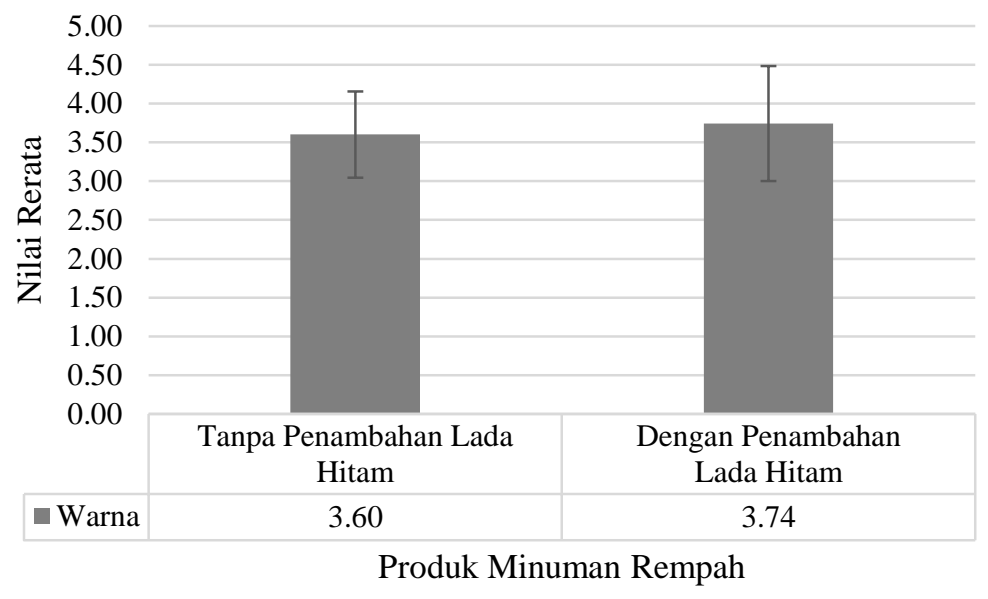

Gambar 3. Nilai Rerata Daya Terima Panelis terhadap Warna Minuman Rempah dengan Penambahan Lada Hitam

Berdasarkan Gambar 3, diketahui nilai rerata daya terima tertinggi terhadap warna yaitu pada minuman rempah dengan penambahan lada hitam. Nilai rerata daya terima terhadap warna produk tersebut sebesar 3,74 $\pm 0,74$ dalam rentang penilaian suka. Berdasarkan uji Mann Whitney U Test, diperoleh nilai Asymp sig 0,143 $(\mathrm{p}<0,05)$. Sehingga, disimpulkan tidak ada perbedaan daya terima terhadap warna antara kedua produk minuman.
Karena tidak ada perbedaan yang signifikan maka dapat dikatakan bahwa tidak ada pengaruh penggunaan lada hitam terhadap warna minuman rempah. Meskipun tidak ada perbedaan yang signifikan, penambahan lada hitam pada minuman rempah menghasilkan warna minuman yang lebih gelap. Warna dari kedua produk minuman dapat dilihat pada Gambar 4.
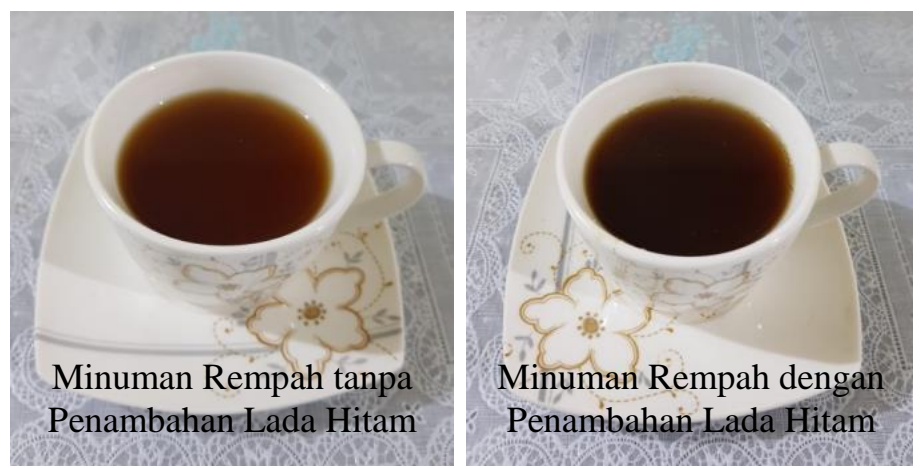

Gambar 4. Minuman Rempah dengan Penambahan Lada Hitam 
Aroma

Nilai rerata daya terima konsumen terhadap aroma minuman rempah dengan penambahan lada hitam dapat dilihat pada Gambar 5.

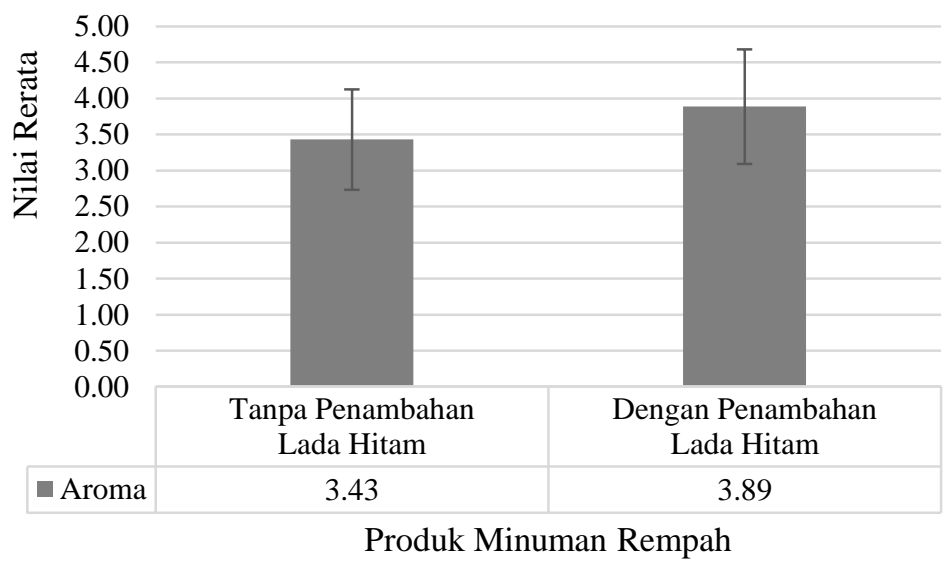

Gambar 5. Nilai Rerata Daya Terima Panelis terhadap Aroma Minuman Rempah dengan Penambahan Lada Hitam

Berdasarkan Gambar 5, diketahui nilai rerata daya terima tertinggi terhadap aroma yaitu pada minuman rempah dengan penambahan lada hitam. Nilai rerata daya terima terhadap aroma produk tersebut sebesar $3,89 \pm 0,80$ dalam rentang penilaian suka. Berdasarkan uji Mann Whitney U Test, diperoleh nilai Asymp sig 0,022 $(\mathrm{p}<0,05)$. Dapat disimpulkan ada perbedaan daya terima terhadap aroma antara kedua produk minuman rempah. Karena ada perbedaan yang signifikan maka dapat dikatakan bahwa ada pengaruh penggunaan lada hitam terhadap aroma minuman rempah.

Penambahan lada hitam pada produk minuman membantu untuk menguatkan aroma jahe, kunyit dan serai, sehingga menghasilkan kombinasi aroma yang pas. Sama halnya dengan rasa, proses penghancuran lada hitam dan pengirisan jahe, kunyit serta serai sebelum direbus dapat mempengaruhi aroma yang dihasilkan. Senyawa pembentuk aroma pada jahe, kunyit, serai dan lada hitam akan terekstrak dengan baik selama proses perebusan. Umumnya, senyawa pembentuk aroma pada jahe, kunyit, serai dan lada hitam berasal dari senyawa aktif yang terkandung di dalamnya (Dyah et al., 2015).

Berdasarkan rekapitulasi produk yang paling disukai, menghasilkan sebanyak 24 panelis atau $69 \%$ panelis lebih memilih produk minuman rempah dengan penambahan lada hitam dan sebanyak 11 Panelis atau 31\% panelis memilih produk standar yaitu minuman rempah tanpa penambahan lada hitam. Tentu hasil ini sejalan dengan hasil uji hedonik.

\section{KESIMPULAN}

\section{Kesimpulan}

Berdasarkan hasil penelitian, dapat disimpulkan bahwa penambahan lada hitam pada minuman rempah menyebabkan perubahan atau perbedaan 
daya terima yang signifikan terhadap rasa dan aroma, tetapi tidak signifikan terhadap warna.

\section{Saran}

Perlu dilakukan penelitian mengenai kandungan gizi dan zat aktif yang terdapat di dalam minuman rempah dengan penambahan lada hitam. Selain itu, jika produk akan diperjualbelikan maka perlu juga dilakukan penelitian mengenai analisis biaya.

\section{DAFTAR PUSTAKA}

A'yunin, N. A. Q., Santoso, U., \& Harmayani, E. (2019). Kajian kualitas dan aktivitas antioksidan berbagai formula minuman jamu kunyit asam. J. Teknologi Pertanian Andalas, 23(1), 37-48. http://tpa.fateta.unand.ac.id/index. php/JTPA/article/view/184

Afifah, F. (2020). Jahe Dan Kunyit Di Sebut Bisa Cegah Virus Corona, Ini Alasanya. The Asian Parent Indonesia.

https://id.theasianparent.com/manf aat-jahe-dan-kunyit

Akbar, Z. (2020). Resep Sehat ala JSR : Hidup Sehat Menebar Manfaat. PT Sygma Media Inovasi.

Antari, A. L. (2017). Imunologi Dasar. Deepublish.

Dyah, R. S., Kiki, W., Lina, I., Kiky, A. D. C., Ferdianto, A. T., Daniar, W. N., \& Nimas, A. A. (2015). Karakteristik Minuman Jahe Merah Secang dengan Perbedaan Cara Pengirisan Jahe.

Hakim, L. (2015). Rempah \& Herba Kebun-Pekarangan Rumah Masyarakat (Issue 164). Diandra.

Mulyani, H., Harti, W. S., \& Indria, E.
V. (2017). Pengobatan Tradisional Jawa dalam Manuskrip. Litera, 16(1), 139-151.

Ningsih, I. Y. (2016). Studi Etnofarmasi

Penggunaan Tumbuhan Obat Oleh

Suku Tengger Di Kabupaten Lumajang Dan Malang, Jawa Timur. Pharmachy, 13(01), 10.

Novitasari, R. (2020). Studi Pengolahan

Serbuk Biji Buah Pokat (Persea Americana Mill) dengan Varians Rasa dari Teh Celup Berbagai Merk dalam Pembuatan Minuman Herbal Kemasan Botolan. Jurnal Teknologi Pertanian, 9(1), 6-13. https://doi.org/10.32520/jtp.v9i1.1 001

Nutrisia, A. S., Dewi, I. K., \& Rusita, Y. D. (2018). Pengembangan Formula Wedang Secang Sebagai Minuman Kemasan Rendah Kalori. Interest : Jurnal Ilmu Kesehatan, 7(1), 8795.

https://doi.org/10.37341/interest.v7 i1.77

Pratama, M. (2017). Identifikasi Atribut Aroma dan Rasa Rempah Dengan Profiled Test. Jurnal Agroindustri Halal, 3(2), 126-132. https://doi.org/10.30997/jah.v3i2.9 03

Rizal Yulianto, R., \& Dewanti Widyaningsih, T. (2013). Formulasi Produk Minuman Herbal Berbasis Cincau Hitam (Mesona Palustris), Jahe (Zingiber Officinale), dan Kayu Manis (Cinnamomum Burmanni). 1(1), 65-77.

Sunaryo, E. S. (2015). Minuman Tradisional Penguat Kekebalan Tubuh. Elex Media Komputindo. 